\title{
Astrokeltoi: an archaeoastronomical project in the Celtiberian area
}

\author{
Javier Mejuto $^{1}$, Maria Luisa Cerdeño ${ }^{2}$, Gracia Rodríguez Caderot ${ }^{3}$ \\ and César Rodríguez ${ }^{1}$ \\ ${ }^{1}$ Departamento de Geofísica y Meteorología \\ Facultad de Ciencias Físicas, Universidad Complutense de Madrid, \\ Ciudad Universitaria s/n, 28040 Madrid, Spain \\ email: jmejugon@fis.ucm.es \\ ${ }^{2}$ Departamento de Prehistoria, \\ Facultad de Geografía e Historia, Universidad Complutense de Madrid, \\ Calle Profesor Aranguren, 28040 Madrid, Spain \\ email: mluisac@ghis.ucm.es \\ ${ }^{3}$ Departamento de Geodesia y Astronomía \\ Facultad de Ciencias Matemáticas, Universidad Complutense de Madrid, \\ Plaza de Ciencias, 3, 28040 Madrid, Spain \\ email: grc@mat.ucm.es
}

\begin{abstract}
We present an archaeoastronomical project as a part of a cultural heritage project on Celtiberian cultures. Following a study on the Iron Age's sky and its relationship with Celtiberian cultures, we present the Celtiberian Archaeological Route. This information is presented to visitors in relation to the landscape and the archaeological site. The ASTROKELTOI project attempts to link the archaeoastronomical popularisation to its cultural and historical frameworks.
\end{abstract}

Keywords. archaeoastronomy, outreach, tourism, Iron Age

\section{Introduction}

This project was born out of our interest for a better knowledge of the relationship that the cultures of Iberian Peninsula had with the sky, especially during the Iron Age. ASTROKELTOI is not just a scientific project, rather, the aim of this project is to link archaeoastronomy, scientific divulgation and society. For this reason, we use an operating cultural route, the Celtiberian Route.

\section{Celtiberia}

In some classical texts, Celtiberia appears described as a mountainous region delimited imprecisely by the Anas and Betis rivers, while other texts are more precise and help us to trace the approximate boundaries from the middle part of the Ebro valley to the source of the Duero River. We will refer here to Celtiberia just as the Romans did in the second century BCE, namely the land occupied by the Arevacos, Pelendones, Lusones, Belos and Titos pre-roman peoples (Burillo 1986, 1993, 1998). 


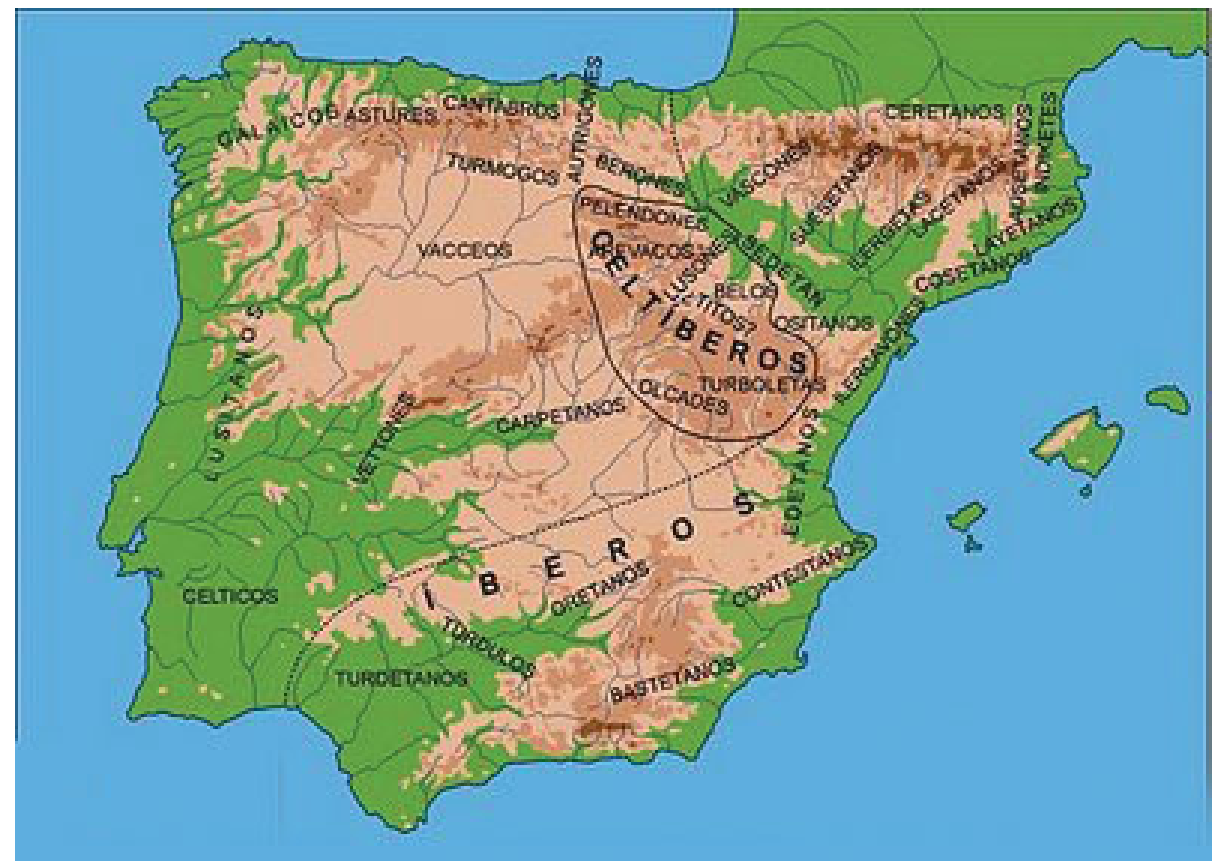

Figure 1. Iberian Peninsula, Celtiberia and Celtiberian tribes near the 2nd century BCE (Centro de Estudios Celtibéricos de Segeda - F. Burillo).

\section{The Celtiberian cultures}

As usual, the name of celtiberians was given by other cultures in antiquity. It seems that the name celtiberians appears for first time in the Greek Annales of Fabius Pictor (Pelegrín 2005) judging by the similarities between the Celts who invaded Italy and the "Iberian Celts". We can find many references to Celtiberian mercenaries coming from mainland in the events which took place during the third century BCE. The word Celtiberian has other meanings at this time, as it may refer to Spanish Celts or Iberian Celts, as opposite to Gauls, for example. Still, with the Roman conquest, we have another meaning involving several tribes: Arevacos, Pelendones, Lusones, Belos and Titos. There were frequent alliances and intertribal wars, both motivated for the same reasons: invaders, self-interest and natural resources. We can say without doubt that celtiberians had neither state nor tribal state, their society evolved into state-cities (third century $\mathrm{BCE}$ ), as the Romans found. We also know that the cultural process of these pre-Roman peoples was much older; current studies point to the seventh century BCE as the date when their cultural features were completely formed.

\section{The Celtiberian route}

This cultural route was developed by Francisco Burillo, professor at the Prehistory Department of the University of Zaragoza, linking the Archaeological Heritage management with the development of an economically depressed area. This initiative belongs to the European framework of cultural routes and the Celtiberian Heritage is arguing for its integration within the World Heritage list. This archaeological route has three basic objectives: (1) to develop an economically depressed area, (2) to spread heritage and scientific knowledge, and (3) to integrate society, science and heritage conservation. 
Table 1. Alignments of the necropolis of the Celtiberian village El Ceremeño to major lunar standstills (from García Caderot et al. 2006).

\begin{tabular}{lrr}
\hline & Azimuth & Declination \\
\hline Major lunar standstill rise & $50^{\circ} .5$ & $28^{\circ} .7$ \\
Major lunar standstill set & $309^{\circ} .5$ & $28^{\circ} .7$ \\
Necropolis alignment (Group I) & $51^{\circ} .99$ & $27^{\circ} .7$ \\
Necropolis alignment (Group II) & $51^{\circ} .38$ & $28^{\circ} .16$ \\
\hline
\end{tabular}

The Celtiberian route covers some $40,000 \mathrm{~km}^{2}$ with a total population of 284,000 inhabitants. The population density is thus 7 inhabitants per $\mathrm{km}^{2}$ which is typical of a desert. Covering $8 \%$ of the total Spanish landscape, the historical region of Celtiberia is occupied by only $0.71 \%$ of the population of the country. Needless to say, this part of the country is one of the most depopulated areas. Its two main cities, Soria and Teruel, are just above the city criteria limit with about 30,000 inhabitants each. The remaining $77.81 \%$ of total population is distributed in 755 little settled areas. In addition, the average age of the population in $40 \%$ of this area is larger than 50 years.

\section{Cultural heritage}

To give a better idea of the cultural heritage which covers the Celtiberian route, we provide here further details on this area. Presently the historical region of Celtiberia covers several Autonomous Comunities. The first one is the closer to the Ebro river, Aragón. There are two important cities, Bílbilis Itálica (Martín Bueno 1975, 1982; Burillo \& Ostaldé 1984) where the Classical poet Marcus Valerio Marcial was born, and Segeda (Burillo \& Ostaldé 1984) one of the most relevant Celtiberian city in classical texts. Further to the South, we find the Celtiberian rural village of Alto Chacón and anthropomorphous figures in Celtiberian sanctuary of Peñalba.

In the Castilla-León region, from North to South, we find the roman city of Clunia, with large Roman thermal baths, and a theatre for an audience of 10,000. The famous Numancia Celtiberian city (Jimeno et al. 2004), where the Roman army leaded by Publius Cornelius Scipio defeated the Celtiberians. The Uxama Celtiberian hill fort played a rôle in helping Numancia to fight against the Romans, ans was destroyed by Cneo Pompeyo Magno in $72 \mathrm{BCE}$. Another important place in this region is Tiermes, one of the most relevant cities in the Roman conquest, and whose existence has been assessed for 35 centuries. It was conquered by the Romans in $98 \mathrm{BCE}$.

La Rioja is another region of Celtiberia. Here we have the Celtiberian-roman city of Contrebia Leucade (Hernández Vera 2003) with a spectacular settlement and the important necropolis of El Castillo. In Castilla-La Mancha we find the Celtiberian city of Segóbriga (Abascal Palazón et al. 2008) named the Celtiberia's head by Pliny and located in the southern extreme of Celtiberia. In this province we find one of the most important mines in Antiquity, with several massive veins of iron, copper and lead. In the province of Guadalajara we find the best examples of small rural settlements, far from big cities of the hill fort type. Our project includes three important Celtiberian settlements, very close to each other: (1) Castilviejo hill fort, with very impressive defensive structures; (2) El Ceremeño village (Cerdeño and Juez 2002), with an interesting habitation pattern and relevant necropolis where researchers of our group found a tomb alignment to the major lunar standstill (see García Caderot et al. 2006, and Table 1); and (3) Los Rodiles (Cerdeño et al. 2008), another hill fort whose excavation has recently been started. 


\section{ASTROKELTOI}

The point we address next is what archaeoastronomy can do in this context. Despite being a new scientific approach, archaeoastronomy is unknown for most of the society, even though it allows us to get information about the relationships between ancient cultures and the sky, and in this way to get closer to their thinking. This new aspect, added to archaeological projects, can be popularised in addition to other cultural aspects.

Probably the best way to do this is linking archaeoastronomy and archaeological sites, by providing both archaeological and archaeoastronomical information to the visitors at the sites. Clearly the best way to understand science is just to experience it in its proper context. Obviously, we cannot deny that archaeoastronomy may interest many people and we can use this to bring more tourism, increasing the economy of these depressed areas, and teaching science and explaining archaeoastronomy at the same time.

An example of a successful relationship between archaeoastronomy, archaeology and tourism is the Kukulkán pyramid in the Chichén Itzá Mayan site. Every Spring equinox many people go to this site to see the pattern of light and shadows marking the movement of Kukulk'an as a solar projection with a snake shape. This effect is used by tourist guides to explain cosmology and symbolism, a difficult thing to do just with archaeology.

In the ASTROKELTOI project we will provide local information for each archaeological site. We will focus on the topoastronomical horizon that the ancient tribes could see from their villages, cities or necropolis. The first step will be the systematic data acquisition based in geodesic methodology in order to find possible alignments related to astronomical events. In this way topography, structures and necropolis will be better studied. Obviously this will be done in close collaboration with the local archaeologists to get a better understanding of the excavation process and the site interpretation. On the other hand, a theoretical work will also be done in order to understand Celtiberian cosmology, immaterial world, and their religious world.

Finally we will get a complete collection of data of the Celtiberian region, separated by historical epochs with resultsthat will be added to the information that visitors will receive. These data will be put in a Geographical Information System and a public web catalogue will be presented for further investigations.

In the archaeological sites, the basic astronomical information will be explained and solar and planetary annual movements will be explained on transparent media in order to see both the real and the modelled ancient sky. Multimedia information will be displayed to connect visitors to our ancestors' world and their vision of the sky.

Astronomical activities will be proposed, especially on astronomically important days, such as during eclipses and solstices and equinoxes. Also educational workshops on ancient astronomical instruments and naked eye observational techniques will be organised. In short, a group of activities to get astronomy, archaeology and archaeoastronomy closer to society.

ASTROKELTOI is an archaeoastronomical project within a scientific-social project. An approach to get a more complete knowledge about the Iron Age peoples in the Iberian Peninsula by integrating archaeological and archaeoastronomical data. An attempt to bridge the social and natural sciences gap, finding new solutions to explain our complex world.

\section{Acknowledgements}

ASTROKELTOI will be carried out within the framework of two projects: Utilización de las técnicas de posicionamiento GPS y diseño de herramientas gráficas para el estudio de enclaves arqueológicos (AYA2008-01214-E/ESP, Gracia Rodríguez Caderot, UCM) 
and Segeda y Celtiberia septentrional: investigación científica, desarrollo rural sostenible y nuevas tecnologías (HAR 2008-04118, Francisco Burillo, Universidad de Zaragoza).

\section{References}

Abascal Palazón, J.M. et al. 2008, Segóbriga 2007: resumen de las intervenciones arqueológicas (Cuenca: Consorcio del Parque Arqueológico de Segóbriga, Tabularium)

Burillo, F. 1986, in Estudios en Homenaje al Dr. Antonio Beltrán Martínez (Zaragoza: Universidad de Zaragoza), p. 529

Burillo, F. 1993, in Leyenda y arqueología de las ciudades prerromanas de la península ibérica $I I$, p. 95

Burillo, F. 1998, Los Celtíberos. Etnias y estados (Barcelona: Editorial Crítica)

Burillo, F. \& Ostalé, M. 1984, Kalathos 3/4, 287

Cerdeño, M.L., Hernández, J. 2007, in Gestión y desarrollo V. Simposio sobre Celtíberos, Francisco Burillo Mozota (ed) (Mara: Centro de Estudios Celtibéricos de Segeda), p. 237

Cerdeño, M.L. \& Juez, P. 2003, El castro celtibérico de El Ceremeño (Herrería, Guadalajara) (Teruel: Seminario de Arqueología y Etnología Turolenses / Junta de Comunidades de Castilla-La Mancha)

Cerdeño, M.L., Rodríguez Caderot, G., Moya, P.R., Ibarra, A. \& Herrero, S. 2006, Trabajos de Prehistoria, 63(2), 13

Cerdeño, M.L., Sagardoy, T., Chordá, M. \& Gamo, E. 2008, Complutum, 19, 173

Hernández Vera, J.A. 2003, Salduie: Estudios de prehistoria y arqueología, 3, 61

Jimeno, A., De La Torre, J.I., Berzosa, R. \& Martínez, J. (eds) 2004, Arqueología en Castilla y León, Memorias, 12 (Valladolid: Junta de Castilla y León)

Lorrio, A. 1997, Los Celtíberos (Madrid: Universidad Complutense de Madrid)

Martín Bueno, M.A. 1975, in Crónicas del XIII Congreso Nacional de Arqueología (Zaragoza: Universidad de Zaragoza), p. 701

Martín Bueno, M.A. 1982, Bajo Aragón Prehistoria, 4, 96

Matías Cruz, J. 2008, Nonnullus, 2, 11

Pelegrín J. 2005, Gerión, 23, 115

Rodríguez Caderot, G., Cerdeño, M.L., Folgueira, M, \& Sagardoy, T. 2006, Complutum, 17, 133

Salinas de Frías, M. 1996, Conquista y romanización de Celtiberia (Salamanca: Ediciones Universidad) 